\title{
TIME TO REVISIT FORUM NON CONVENIENS IN THE UK? GROUP JOSI REINSURANCE CO V UGIC
}

\author{
Christopher D Bougen*
}

There has been much debate in the United Kingdom over the last decade on whether the discretionary doctrine of forum non conveniens is compatible with the mandatory provisions of the Brussels Convention on jurisdiction issues in the European Union. A recent decision of the European Court of Justice has answered affirmatively the question of whether a plaintiff domiciled in a non-Contracting State can invoke the rules of the Covention. The Court has arguably not settled the more fundamental question of whether the Convention applies to conflicts of jurisdiction between courts of a Contracting State and non-Contracting State. However, there is evidence of a growing acceptance of an expansive view of the scope of the Convention. Such a development would bring welcome simplicity to cross-border litigation in the UK.

\section{INTRODUCTION}

The Brussels Convention on Jurisdiction and the Enforcement of Judgments in Civil and Commercial Matters 1968 (Brussels Convention) was created for the purpose of addressing questions of jurisdiction arising among member states of the European Union by providing mandatory rules for determining jurisdiction in matters that come within the scope of the Convention. The Convention provides that as a general rule the courts of the defendant's domicile are to have jurisdiction, ${ }^{1}$ subject only to the limited specific exceptions provided for in the Convention. ${ }^{2}$

* LLB (Kobe University, Japan); LLM (Kobe University, Japan). This paper was produced in the context of the LLB(Hons) writing programme at Victoria University of Wellington.

1 Brussels Convention on Jurisdiction and the Enforcement of Judgments in Civil and Commercial Matters 1968, art 2 [Brussels Convention].

2 See Brussels Convention, Title II ss 2-6. Sections 2 to 4 provide for the additional option of bringing proceedings in, for example, the place of performance of a contract, or the place where the harmful event occurred. Section 5 provides for exclusive jurisdiction for actions in rem in immovable property or those relating to intellectual property rights requiring registration. Section 6 provides for the determination of jurisdiction on the basis of choice of forum clauses. 
The consistency of the Convention with the idiosyncratic UK doctrine of forum non conveniens $^{3}$ has been the subject of much debate over the last decade. The common law power to grant a stay ${ }^{4}$ survives statutorily under section 49 of the 1982 Act incorporating the Convention into UK law, in so far as it is not inconsistent with the principles of the Brussels Convention.

The leading UK case on the compatibility of the Brussels Convention with the doctrine of forum non conveniens is In re Harrods (Buenos Aires) Ltd. ${ }^{5}$ In this case the Court of Appeal held that while a stay on the grounds of forum non conveniens was not available in cases where the two competing jurisdictions were both Contracting States (ie UK and another Contracting State), ${ }^{6}$ there was nothing to prevent a grant of a stay when the "conflict" is between the courts of England and the courts of a non-Contracting State. ${ }^{7}$ The scope of the Convention, then, was the determinative issue.

Commentators have long pointed out that the lack of explicit reference within the Convention about the precise limits of its international operation has always been problematic and has contributed in large part to the uncertainty in the law regarding the Convention. ${ }^{8}$ A recent case decided by the European Court of Justice (ECJ) may have gone some way towards clarifying the extent of the scope of application of the Convention.

\section{THE GROUP JOSI CASE}

The facts that gave rise to this case are as follows. The respondent, a Canadian insurance company, entered into a reinsurance contract with the appellant, a company domiciled in Belgium. The contract had been brokered by a French company, acting as agent of the respondent. Group Josi had been informed by the French agent that the main shareholders in the reinsurance contract were two US reinsurance companies. Immediately prior to the acceptance of the reinsurance offer by Group Josi, the two US companies

3 Within the EU, only the courts in the UK and Ireland recognise this discretionary power. See Mathias Reimann Conflict of Laws in Western Europe (Transnational Publishers, New York, USA, 1995) 82.

4 The leading case is Spiliada Maritime Corporation v Cansulex Ltd (The Spiliada) [1987] AC 460 per Lord Goff of Chieveley.

5 In re Harrods (Buenos Aires) Ltd [1992] Ch 72 [Harrods].

6 Harrods, above n 4, 93.

7 Harrods, above $\mathrm{n} 4,97$.

8 See, for example, Adrian Briggs "Forum Non Conveniens and the Brussels Convention Again" (April 1991) 107 LMCLQ 180, 182.

9 Group Josi Reinsurance Company SA v Universal General Insurance Company [2000] ILPr 549 (ECJ); [2001] QB 68 [Group Josi]. 
informed the French agent that they intended to pull out of the reinsurance contract. This information was not passed on to Group Josi.

When the French agent sent Group Josi a statement of account a year later showing the amount owing in respect of Group Josi's share of the risk, Group Josi, which by this time had learned of the decision of the two US companies to exit the deal, refused to pay, claiming that it had been induced to enter into the reinsurance contract on the basis of information which subsequently proved to be false.

UGIC brought proceedings against Group Josi in France. Group Josi argued that the French courts lacked jurisdiction because the courts in Belgium had jurisdiction, pursuant to the Brussels Convention, based on the fact that the defendant's registered office was in Belgium. The French court rejected this submission, holding that the Brussels Convention did not apply in respect of a Canadian company, and that the French courts had jurisdiction by virtue of French domestic law. ${ }^{10}$

Group Josi appealed this ruling to the Versailles Court of Appeal. The Court observed that the question of whether the specific rules of the Convention can be used against a plaintiff domiciled in a non-Contracting State involves the question of extending Community law to non-member countries. Recognising that a decision on this question required an interpretation of the Convention, the Court referred the matter to the European Court of Justice(ECJ) for a preliminary ruling.

The ECJ was asked: "Does the Brussels Convention apply not only to intra-Community disputes but also to disputes which are integrated into the Community? More particularly, can a defendant established in a Contracting State rely on the specific rules on jurisdiction set out in that Convention against a plaintiff domiciled in Canada?"11

In its judgment, the Court began by outlining the general scheme of the Convention as it relates to determination of jurisdiction. It noted that article 2 sets out the general rule that persons domiciled in a Contracting State are to be sued in the courts of that State, irrespective of the nationality of the parties. ${ }^{12}$

This fundamental principle may be derogated from in certain instances. The Court noted two categories of cases. First, where the fact situation is covered by a rule of special jurisdiction, the defendant may be excluded from the jurisdiction of the courts of the State in which it is domiciled and sued in a court of another Contracting State. Second, where a

10 Group Josi, above n 9, para 26.

11 Group Josi, above n 9, para 32.

12 Group Josi, above n 9, para 34. 
situation is covered by a rule of exclusive jurisdiction in relation to certain subject-matter, or a prorogation of jurisdiction, for example, on the basis of a choice of forum clause, the defendant must be excluded from the jurisdiction of the courts of the State in which it is domiciled and sued in a court of another Contracting State. None of these specific rules were held to be relevant in this case.

The Court found, then, that it is only in quite exceptional cases that the domicile of the plaintiff is decisive in conferring jurisdiction. ${ }^{13}$ They concluded on the basis of their analysis of the scheme of the Convention that as a general rule the domicile of the plaintiff is not relevant for the purpose of determining jurisdiction pursuant to the Convention. Application of the rules of jurisdiction provided for in the Convention is dependent solely on the criterion of the defendant being domiciled in a Contracting State. ${ }^{14}$ This led to the conclusion that the rules of jurisdiction in the Convention may be applied to a dispute between a defendant domiciled in a Contracting State and a plaintiff domiciled in a nonmember country. ${ }^{15}$

\section{THE UK VIEW ON THE SCOPE OF THE BRUSSELS CONVENTION AND FORUM NON CONVENIENS}

While the ECJ was clear that the principles laid down by the Convention can be invoked by domicilaries of non-Contracting States, what is less clear are the implications of such a finding. Some commentators immediately sounded the death-knell for the doctrine of forum non conveniens, suggesting that a stay on the grounds of forum non conveniens is no longer available whenever the defendant is domiciled in the UK. ${ }^{16}$ It is questionable, however, whether Group Josi has this effect.

At the present time, the UK courts undoubtedly still regard Harrods as being the law. In Ace Insurance, ${ }^{17}$ the Court of Appeal applied Harrods and upheld a lower court ruling, decided around the same time as Group Josi, that there was still a discretion to grant a stay of proceedings on the grounds of forum non conveniens where the English court had

13 Group Josi, above n 9, para 47.

14 Group Josi, above n 9, para 57.

15 Group Josi, above n 9, para 59.

16 Douglas Peden "Litigator's View" The Lawyer 4 September 2000, 13; John Melville Williams "Forum Non Conveniens, Lubbe v Cape and Group Josi v Universal General Insurance" (2001) 1 JPIL 72,77 .

17 Ace Insurance SA-NV v Zurich Insurance Company and Zurich America Insurance Company [2001] EWCA CIV 173 [Ace Insurance (CA)]. 
jurisdiction by virtue of the Lugano Convention, a convention complementary to the Brussels Convention. ${ }^{18}$

It is also clear that Harrods is itself somewhat controversial. The House of Lords, after hearing arguments from the parties for several days, referred the matter to the ECJ. However the case was ultimately settled without the European Court issuing a ruling. ${ }^{19}$ Similarly, in the more recent case of Lubbe $v$ Cape $\mathrm{Plc}^{20}$, the House of Lords again recognised the controversy and commented that were the case to turn on this issue, a ruling from the ECJ on the applicability of article 2 of the Brussels Convention would have been necessary. Indeed Lord Bingham hinted there that the correctness of Harrods is an issue and that whether article 2 of the Convention applies is not clear. ${ }^{21}$

So given the controversy surrounding the compatibility of the doctrine of forum non conveniens and the Brussels Convention, does the ECJ ruling in Group Josi change anything? From the point of view of the UK courts the primary concern is whether exercise of the discretion is incompatible with the Brussels Convention, in terms of section 49 of the Civil Jurisdiction and Judgments Act 1982. Following the line of reasoning developed by the Court in Harrods, this will turn on the interpretation of the scope of the Brussels Convention.

The Court of Appeal in Harrods agreed in principle that a stay on the grounds of forum non conveniens was not available in cases where the two competing jurisdictions were both Contracting States (ie England and another Contracting State) ${ }^{22}$ However it found that there was nothing to prevent the application of the doctrine when the "conflict" is between the courts of England and the courts of a non-Contracting State. In the Court's view, the Convention did not apply.

In arriving at this decision, the Court considered the true construction of the Brussels Convention. ${ }^{23}$ Dillon LJ saw the Convention as implementing the aim of article 220 of the EU Treaty which was essentially to simplify formalities between EU states. A common basis of international jurisdiction in matters which fall within the scope of the Convention

18 The Lugano Convention is an agreement between the EU members and the members of EFTA (European Free Trade Area). It is almost identical to the Brussels Convention and functionally it extends the jurisdictional rules of the Brussels Convention beyond the EU to the EFTA states.

19 Ace Insurance (CA), above n 17, para 28.

20 Lubbe v Cape plc [2000] 4 All ER 268.

21 Lubbe v Cape plc, above n 19, 282.

22 Harrods, above n 4, 93.

23 Harrods, above n 4, 95. 
was seen as important in achieving this goal. ${ }^{24}$ Given that the Convention was merely an agreement between the Contracting States among themselves, Dillon LJ did not feel that the framework of the Convention would be destroyed if there were available to the English court a discretion to refuse jurisdiction on the ground that the courts of a non-Contracting State were the appropriate forum, in a case with which no other Contracting State was concerned. ${ }^{25}$

In Group Josi, the ECJ was clear that the domicile of the plaintiff was not relevant for the purpose of applying the rules of jurisdiction laid down by the Convention, and that the Convention can apply to a dispute between a defendant domiciled in a Contracting State and a plaintiff domiciled in a non-member country. However, the ECJ did not expressly address the question of which cases the Brussels Convention can apply to.

There is a difference between who can invoke the principles of the Convention and when the principles of the Convention apply. In the Group Josi case, despite the fact that the plaintiff was domiciled in a non-Contracting State, the conflict of jurisdiction was between the courts of two Contracting States: the plaintiff contended that the courts of France had jurisdiction, while the defendant contended that the courts of Belgium had jurisdiction. Thus, the conflict was between courts of two Contracting States, and it is no surprise that the ECJ found the Convention applied to determine jurisdiction. On this interpretation, the decision in Group Josi does not break any significant new ground; it merely confirms that it is possible for a domiciliary of a non-Contracting State to invoke the Convention when there is a conflict of jurisdiction between Contracting States. The scope of application does not change from the Court's interpretation in Harrods. The discretionary power to grant a stay on forum non conveniens grounds would not be available.

Could, then the mandatory rules of the Convention apply to a situation where a domiciliary of a non-Contracting State sues a domiciliary of a Contracting State, and the conflict of jurisdiction is between courts of those two states or even a third country, also not a Contracting State, thereby precluding the availability of a plea of forum non conveniens? The ECJ's decision does not expressly address this point. If the case is read as determining when the Convention can apply as distinct from who can invoke the Convention, then this would represent a different and expansive view of the scope of the Convention, and would overrule the view of the Court of Appeal in Harrods. A discretionary stay on the grounds of forum non conveniens would not be available whenever the defendant was domiciled in the UK, as it is inconsistent with the

24 Harrods, above n 4, 96.

25 Harrods, above n 4, 97. 
Convention. It is submitted that, while this interpretation may be a welcome outcome, it may be questioned whether Group Josi goes this far.

\section{REEXAMINING FORUM NON CONVENIENS IN LIGHT OF GROUP JOSI}

Crucially, however, the ECJ could be read as addressing a key concern of the UK Court of Appeal in Harrods. Dillon LJ remarked that if article 2 of the Convention has full mandatory effect in cases where the defendant is domiciled in England and the plaintiff is domiciled overseas, an agreement between the parties to submit to the jurisdiction of a foreign court would be useless, as English courts would find themselves bound to hear the case pursuant to the mandatory provisions of article 2. However, the ECJ stated that special rules of exclusive jurisdiction as provided in article 17 are equally applicable if the defendant is domiciled in a Contracting State and the plaintiff is domiciled in a nonmember country. ${ }^{26}$ Thus a choice of forum clause would be upheld under the Convention, even where the defendant is domiciled in a Contracting State.

Furthermore, there is evidence that UK courts are prepared to accept an expansive application of the principles of the Convention and hold that exclusive jurisdiction clauses of the kind countenanced by article 17 should be applied even where the clause was in favour of a non-Contracting State. In Ace Insurance, the trial judge, Longmore J, remarked that it would be odd if an agreement to submit to the jurisdiction of the Courts of a nonContracting State had to be treated as ineffective in any Convention country. ${ }^{27}$

On the basis of this, the reasoning of the Court of Appeal in Harrods begins to break down. If the court was faced with a situation where the parties were both domiciled in Contracting States and there was an agreement between the parties to submit to the jurisdiction of the courts of a non-Contracting State, would the Court of Appeal, given that the case involves a dispute between two domiciliaries of Contracting States, apply the mandatory provisions of the Convention and hold that the case must be heard in England? It is submitted that the UK courts would uphold the choice of forum clause, even though there is a conflict of jurisdiction between courts of a Contracting State and those of a nonContracting State. ${ }^{28}$ Logically, this suggests one of three conclusions:

(1) the mandatory provisions of the Convention are not so mandatory after all;

26 Group Josi, above n 9, paras 41-42.

27 Ace Insurance SA-NV v Zurich Insurance Co and Zurich America Insurance Co [2000] 2 Lloyd's Rep 423, para 21, (QB) [Ace Insurance $(Q B)]$.

28 Indeed, this much can be said given the remarks by Longmore J in Ace Insurance (QB), above n 27, para 21. 
(2) the distinction between domiciliaries and courts of Contracting States and those of non-Contracting States is not a tidy one;

(3) the rules of the Convention can be held to apply in circumstances analogous to the provisions of the Convention. Thus, the choice of forum clause would be upheld, granting exclusive jurisdiction to the chosen forum pursuant to article 17, applied mutatis mutandis. ${ }^{29}$

The first proposition would totally undermine the Convention. Arguably, the better view is a combination of the latter two propositions. In short, the Convention can only operate logically if it is read as being equally applicable in a situation where the defendant is domiciled in a Contracting State and the plaintiff in a non-Contracting State, and where there is a conflict of jurisdiction between the courts of Contracting State and nonContracting State.

\section{THE FUTURE OF FORUM NON CONVENIENS IN THE UK}

Simplicity and predictability are aims equally applicable to disputes which transcend the EU and those internal to the EU. This view can be supported by the protracted interlocutory litigation that occurred in the Lubbe $v$ Cape plc case ${ }^{30}$ which involved a personal injury claim by South African workers who suffered disease (in some cases died) from working in an asbestos mine owned and operated by a company domiciled in the UK. The plaintiffs commenced proceedings for compensation in the UK courts, but were immediately meet by a barrage of interlocutory motions, including an application for a stay of proceedings on the ground of forum non conveniens. The defendant argued that the case should be heard in South Africa. After no less than three first instance hearings, two appeals to the Court of Appeal and finally a House of Lords decision, the defendant's application for a stay was denied; the plaintiffs would get their day in a UK court. This merry-go-round of interlocutory litigation could have been avoided if the Brussels Convention had, from the outset been held to apply. On the basis that the defendant was domiciled in the UK, the UK courts would have jurisdiction under article 2 of the Convention, and the possibility of a stay on the ground of forum non conveniens would be unavailable.

There is much to be said for certainty and the avoidance of protracted interlocutory litigation, particularly in cases of a transnational nature where the potential for burgeoning litigation costs is apparent. Extending the scope of application of the Brussels Convention

29 The UK courts have already made judicial reference to academic discussion of application of Convention principles by analogy. See Ace Insurance (CA), above n 17, para 40 .

30 Lubbe v Cape plc [2000] 4 All ER 268 (HL). 
would go a long way towards achieving this in situations where a defendant domiciled in the UK is being sued in UK courts. Group Josi arguably settles the question of whether the fact that one of the parties is not a domiciliary of a Contracting State will prevent the Brussels Convention from being invoked. Clearly the court found it will not. While the Group Josi case arguably does not settle the matter, in that it does not expressly address the issue of the application of the Convention to a situation where there is a conflict of jurisdiction between the courts of a Contracting State and those of a non-Contracting State, it most certainly should be seen as an important step in the right direction. The need for a conclusive decision on this matter is apparent.

The implication for companies and practitioners in non-European countries contemplating the future possibility of litigating in the UK is clear. The Brussels Convention may be poised to become the sole determinant of jurisdiction disputes. 
